\title{
Short communication: Glucose kinetics in dairy heifers limit- fed a low- or high-forage ration at 4 levels of nitrogen intake ${ }^{1}$
}

\author{
G. I. Zanton ${ }^{* 2}$ and A. J. Heinrichs† \\ *USDA-Agricultural Research Service, US Dairy Forage Research Center, Madison, WI 53706 \\ †Department of Animal Sciences, The Pennsylvania State University, University Park 16802
}

\begin{abstract}
The objective of this research was to evaluate the effect of level of forage and $\mathrm{N}$ intake on glucose kinetics in growing dairy heifers. Eight Holstein heifers (beginning at $362 \pm 7 \mathrm{~kg}$ of body weight and $12.3 \pm 0.4 \mathrm{mo}$ of age) were fed 8 rations according to a split-plot, 4 $\times 4$ Latin square design with rations containing either high ( $75 \%$ forage dry matter) or low (25\% forage dry matter) levels of forage and 4 levels of $\mathrm{N}$ intake (0.94, $1.62,2.30,2.96 \mathrm{~g}$ of $\mathrm{N} / \mathrm{kg}$ of metabolic body weight per day). Diets were limit-fed to maintain equal predicted metabolizable energy intake over the four 28-d periods; dietary $\mathrm{N}$ was increased through the substitution of high-N ingredients for corn. Blood samples were collected from all heifers at times throughout d 18 to 19 to characterize glucose concentration over the course of a day, and glucose tolerance tests were conducted over the last $8 \mathrm{~d}$ of each period (1 heifer/d) at $4 \mathrm{~h}$ before feeding. Glucose concentration transiently declined after feeding for all dietary groups, but we found no evidence of a differential response over time that could be attributed to diet. When averaged over a day, glucose concentration was affected by an interaction between level of forage and $\mathrm{N}$ intake; however, this response appeared related more to the level of starch in the diet than to the effects of either forage or $\mathrm{N}$ intake per se. Early-phase kinetic response of glucose disposal after an intravenous glucose bolus was not affected by dietary treatment, which is consistent with no difference in area under the curve through $30 \mathrm{~min}$. Area under the curve through 120 min tended to linearly decrease with decreasing dietary $\mathrm{N}$ intake. This response corresponded to the kinetic analysis, in which heifers consuming higher $\mathrm{N}$ intake had an attenuated return to baseline glucose levels. Additionally, heifers consuming
\end{abstract}

\footnotetext{
Received September 23, 2016.

Accepted December 23, 2016.

${ }^{1}$ Mention of any trademark or proprietary product in this paper does not constitute a guarantee or warranty of the product by the USDA or the Agricultural Research Service and does not imply its approval to the exclusion of other products that also may be suitable.

${ }^{2}$ Corresponding author: geoffrey.zanton@ars.usda.gov
}

lower $\mathrm{N}$ intake maintained a period of glucose concentration below baseline before returning to baseline. We concluded that the response to an intravenous glucose bolus differs in dairy heifers fed diets differing in $\mathrm{N}$ intake, whereas forage level did not affect this response. This should be considered when formulating rations for low $\mathrm{N}$ intake by replacing high- $\mathrm{N}$ for high-starch feedstuffs when limit-feeding dairy heifers.

Key words: dairy heifers, limit feeding, glucose kinetics

\section{Short Communication}

Glucose metabolism in ruminants is known to differ from nonruminants because of the microbial fermentation of dietary carbohydrates to VFA in the rumen (Van Soest, 1994). Glucose requirement by tissues must be met by gluconeogenesis from propionate, AA, and lactate (Larsen and Kristensen, 2013). Reynolds et al. (1991a,b) investigated the effects of differing the proportions of forage and concentrate in rations fed to growing beef heifers on energy metabolism at the level of the whole animal as well as for the portal drained viscera tissues and the liver. Glucose release to the periphery was significantly increased when feeding a low-forage ration, possibly due to the decreased glucose metabolism by the portal-drained viscera, as glucose output by the liver was not significantly different between diets (Reynolds et al., 1991a). Frequently, dairy heifers are fed diets that are high in forage to reduce voluntary DMI and maintain ADG and body composition within acceptable ranges to meet age at first calving goals without having detrimental effects on subsequent milk production (Zanton and Heinrichs, 2005). However, several studies have been conducted that have evaluated limit-feeding in dairy heifers, potentially with higher-concentrate diets, as a management practice to increase feed efficiency while maintaining growth targets (Ding et al., 2015; Lascano et al., 2015; Zanton and Heinrichs, 2016). Lower fiber intakes under these situations could result in alterations in glucose utilization when diets are fed to maintain isoenergetic conditions. 
Nitrogen consumption and utilization by dairy heifers has been studied to a limited extent compared with dairy cows (NRC, 2001). Many experiments with lactating dairy cows or growing beef cattle have shown that the metabolism of protein and carbohydrate metabolism are integrated (Richards et al., 2002; Hall, 2013; Cantalapiedra-Hijar et al., 2014). In a study that limit-fed dairy heifer diets with different levels of forage and $\mathrm{N}$, it was shown that $\mathrm{N}$ retention increased with increasing $\mathrm{N}$ intake, which occurred independent of level of forage (Zanton and Heinrichs, 2009). To our knowledge, no data are currently available regarding the responses of both altered forage-to-concentrate ratio and dietary protein on the kinetics of glucose utilization in weaned dairy heifers. Therefore, the objective of the current research was to evaluate the effect of level of forage and $\mathrm{N}$ intake on glucose kinetics in growing dairy heifers. We hypothesized that reducing forage and $\mathrm{N}$ intake would result in increased glucose rate of clearance.

All procedures involving the use of animals were approved by the Pennsylvania State University Institutional Animal Care and Use Committee. The methods for this experiment have been described in detail previously (Zanton and Heinrichs, 2009). Briefly, 8 Holstein heifers $(12.3 \pm 0.4 \mathrm{mo}$ and $362 \pm 7 \mathrm{~kg}$; initial age and weight, respectively) were randomly assigned to 2 forage levels and to an $\mathrm{N}$ intake sequence within forage level administered according to a split-plot, $4 \times 4$ Latin square design with 28 -d periods. The whole plot factor is the proportion of forage in the diet [low forage $(\mathbf{L F})$ : $25 \%$ of DM; high forage (HF): $75 \%$ of $\mathrm{DM}$ ) and the subplot is the level of $\mathrm{N}$ intake, which were formulated to be 1.00 (Low), 1.67 (MLow), 2.33 (MHigh), and 3.00 (High) g of $\mathrm{N} / \mathrm{kg}$ of metabolic BW $\left(\mathrm{BW}^{0.75}\right)$ per day. Level of DMI was limited so that both forage levels were calculated to provide equal intakes of $\mathrm{ME}(0.2$ Mcal of $\mathrm{ME} / \mathrm{kg}$ of $\mathrm{BW}^{0.75}$ ) and to meet the $\mathrm{N}$ intake targets for the treatments. Alterations in $\mathrm{N}$ concentration were made by the substitution of high- $\mathrm{N}$ feedstuffs for corn in both forage levels without changing the forage components (corn silage and wheat straw) of the diet; the complete ingredient and chemical composition has been reported previously (Zanton and Heinrichs, 2009). Heifers were individually fed treatment TMR at 1200 $\mathrm{h}$ and water was available for ad libitum consumption. Adaptation to treatment rations were made over the first $18 \mathrm{~d}$ of each period, followed by $10 \mathrm{~d}$ of sampling.

Between 0600 and $0800 \mathrm{~h}$ on d 18, heifers were catheterized in the right jugular vein (16 gauge, $13.3 \mathrm{~cm}$; BD Angiocath, Franklin Lakes, NJ) and blood was sampled into heparinized sample tubes at times relative to feeding of $0,1,2,3,4,5,6,7,8,10,12,16,20$, and
$24 \mathrm{~h}$. Immediately after sampling at each time point, blood was centrifuged at $4,000 \times g$ at $4^{\circ} \mathrm{C}$ for $15 \mathrm{~min}$, plasma was aspirated, and blood was stored at $-20^{\circ} \mathrm{C}$ until analysis for glucose (procedure no. 1075; Stanbio Laboratory Inc., San Antonio, TX). On d 21 to 28, glucose tolerance tests were performed to assess the kinetics of glucose as affected by the differing levels of forage and the different levels of nitrogen intake. One heifer per day for d 21 to 28 was catheterized in both jugular veins at approximately $0600 \mathrm{~h}$ (16 gauge, 13.3 cm; BD Angiocath); at $0800 \mathrm{~h}$ ( $4 \mathrm{~h}$ before feeding), a glucose bolus was delivered through one of the catheters at a rate of $300 \mathrm{mg} / \mathrm{kg}$ of BW over 3 min (Dextrose $50 \%$ solution, AgriLabs, St. Joseph, MO). The original intention of this study was to conduct a minimal model analysis of the insulin-modified frequently sampled intravenous glucose tolerance test (Saad et al., 1994); therefore, at $20 \mathrm{~min}$ after the glucose dosing, an insulin bolus (Humulin R, Eli Lilly and Co., Indianapolis, IN) of $30 \mathrm{mU} / \mathrm{kg}$ of $\mathrm{BW}$ was administered through the jugular infusion catheter. Blood was sampled into heparinized sample tubes or serum tubes from the second catheter at $1,2,3,4,5,6,7,8,10,12,14,16,19$, $22,23,24,25,27,30,35,40,50,60,70,80,90,100$, 120,150 , and $180 \mathrm{~min}$ after the conclusion of glucose administration (Saad et al., 1994). Heparinized blood samples were maintained on ice for a maximum of 30 min before centrifuging at $4,000 \times g$ at $4^{\circ} \mathrm{C}$ for $15 \mathrm{~min}$, plasma was aspirated, and blood was stored at $-20^{\circ} \mathrm{C}$ until analysis for glucose (procedure no. 1075; Stanbio Laboratory Inc., San Antonio, TX) or serum insulin (Siemens Coat-A-Count Insulin RIA, Siemens Medical Solutions Diagnostics, Los Angeles, CA). Although insulin data for period 1 responded as expected, for an unknown reason, analyzed insulin was extremely low and variable during periods 2 to 4 ; these data were thus rejected as unreliable and the focus for the remainder of the discussion will be on glucose.

Plasma glucose kinetic response to intravenous glucose administration was modeled using the following model:

$$
\text { Plasma glucose, } \mathrm{mg} / \mathrm{dL}=G_{0} e^{-k_{g} t}+G_{b}\left(1-e^{-k_{g} t}\right)^{w},
$$

where $G_{0}$ is the intercept predicted at time $=0 ; e$ is the natural logarithm; $k_{q}$ is the fractional rate of plasma glucose clearance; $t$ is the time (min); $G_{b}$ is the glucose concentration predicted at an infinite time after glucose administration; and $w$ affects the rate of approach to $G_{b}$, where a higher value for $w$ represents a prolonged long-term response to the glucose bolus. The use of this equation allowed the use of all glucose concen- 
tration data over the 180-min test and accounted for the observed characteristics of the response, including instances where glucose concentration declined below baseline and subsequently increased to $G_{b}$ (when $w$ is higher). Glucose tolerance data were fit to individual response profiles for times greater than 5 min (to allow for distribution of the glucose bolus) for each heifer-period using the NLIN procedure of SAS (SAS Institute, 2013). Area under the curve (AUC) was calculated using the trapezoidal rule for the ranges of $5 \leq$ time $\leq 30 \min ($ AUC30) and $5 \leq$ time $\leq 120 \min ($ AUC120) to characterize the initial and long-term responses to glucose administration, respectively. Data, including glucose kinetic parameter estimates, were analyzed as a split-plot, Latin square design with fixed effects of period, forage, $\mathrm{N}$ intake level, and forage $\times \mathrm{N}$ intake interaction and a random effect of heifer (forage) in the mixed procedure of SAS. Correlation between residuals was modeled using the first-order ante-dependence covariance structure when multiple observations were made over time within heifer within period. Due to the heteroscedasticity of the glucose response to intravenous glucose administration, these data were first $\log _{\mathrm{e}^{-}}$ transformed before calculating the least squares means; however, the kinetic analysis was conducted on the untransformed data. The effect of forage was evaluated with the denominator degrees of freedom and the error term associated with whole plot error of heifer (forage), whereas the effect of $\mathrm{N}$ intake and the interaction were evaluated against the pooled residual error. Preplanned contrasts of interest were the main effect of forage level, the linear and quadratic effect of $\mathrm{N}$ intake, and the linear and quadratic interactions between forage level and $\mathrm{N}$ intake. Least squares means are presented in tables and evidence for statistical significance was declared at $P<0.05$.

As previously reported (Zanton and Heinrichs, 2009) and as planned, $\mathrm{N}$ intake increased linearly with $\mathrm{N}$ treatment and NDF intake was greater for HF than LF. Due to the substitution strategy that was employed in our experiment, changes in high-protein feedstuffs, cracked corn, and forage level, including corn silage, resulted in a linear increase in starch intake over all dietary treatments. To maintain predicted isoenergetic intakes, DMI was lower for heifers fed LF $(6.6 \mathrm{~kg} / \mathrm{d})$ than HF $(7.4 \mathrm{~kg} / \mathrm{d})$. As reported previously (Coggins and Field, 1976; Bines and Davey, 1978), plasma glucose concentration declined after feeding, as shown in Figure 1 ; however, the time-course of this response was not differentially affected by dietary treatment $(P>0.20)$. Increasing glucose concentrations after feeding has also been observed (Evans et al., 1975; Jenny and Polan,

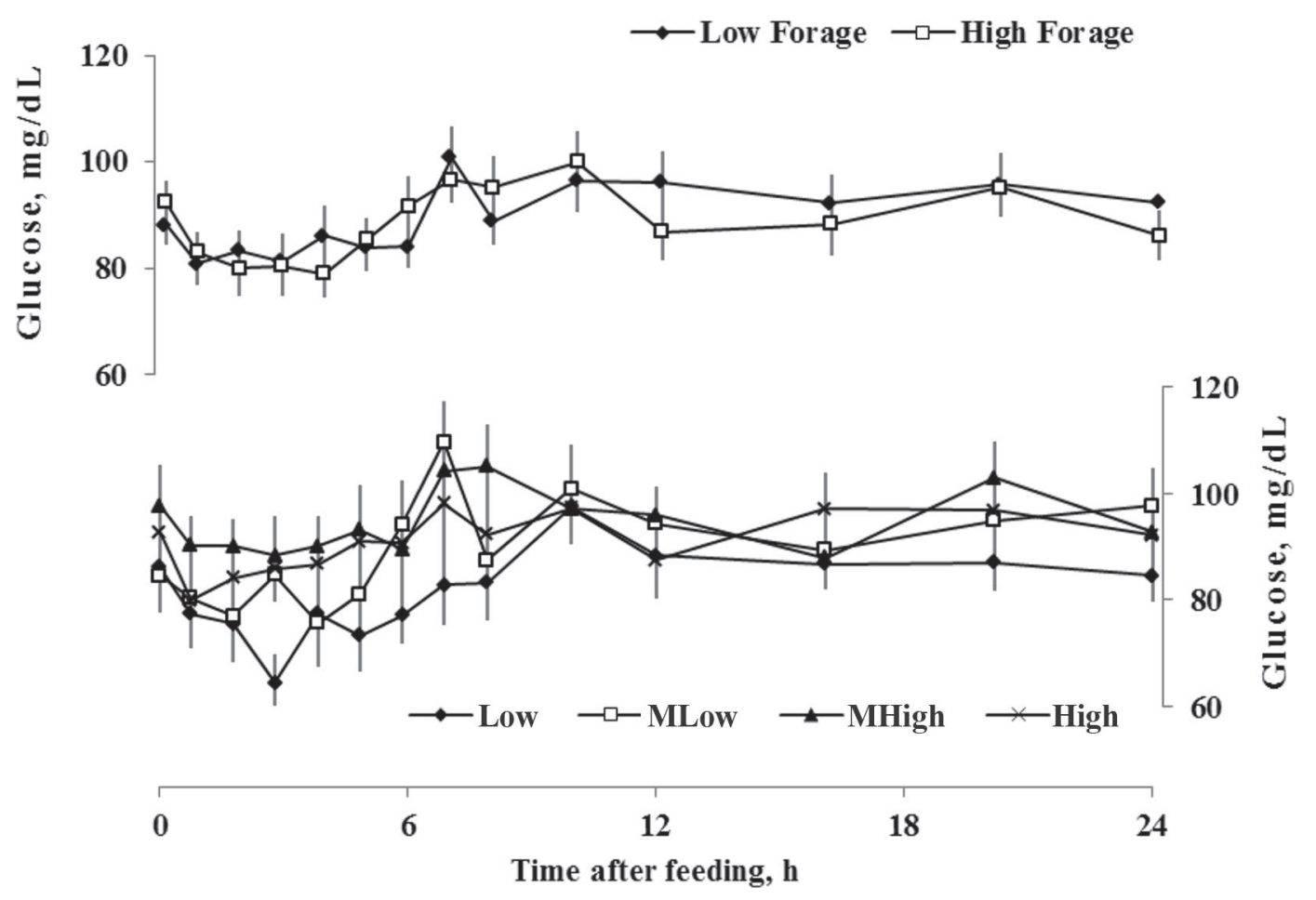

Figure 1. Within-day variation of plasma glucose concentration for dairy heifers limit-fed low- or high-forage diets with 4 levels of nitrogen intake. Nitrogen intakes were formulated to be 1.00 (Low), 1.67 (MLow), 2.33 (MHigh), and 3.00 (High) g of N/kg of metabolic BW (BW per day. Error bars are SEM for each time point. 
1975), although more factors than feeding that may contribute to the postprandial glucose response, such as circadian rhythms or feeding schedules (Niu et al., 2014). Neither forage level nor $\mathrm{N}$ intake level resulted in differences in glucose concentration throughout the day when averaged $(\mathrm{AUC} / 24 \mathrm{~h})$ to represent a daily glucose concentration; however, a significant linear interaction between forage and $\mathrm{N}$ intake was observed (Table 1). This response could be due to a reduced small intestinal digestibility of dietary starch when starch intake is high and $\mathrm{N}$ intake is low (Richards et al., 2002), as it is for LF-MLow and LF-Low. Additionally, considering the opposing direction of the plasma glucose response to $\mathrm{N}$ intake for LF and HF and evaluating the relationship between dietary treatments and starch intake, an association was evaluated between daily glucose concentration and starch intake. A significant quadratic response $(P<0.05)$ in daily glucose concentration was observed over the $\sim 2.5$-fold change in starch intake across diets (Figure 2). These results are consistent with the infusion studies reported by Kreikemeier et al. (1991), in which plasma glucose concentration numerically or sig- nificantly responded quadratically to increased starch and corn dextran infusion rate, respectively. Ultimately, the mechanism responsible for this relationship between diet and plasma glucose concentration is not available from the results of our study.

Glucose concentration before the initiation of the glucose tolerance test was not affected by any dietary treatment (Table 1). Likewise, the observed maximum glucose concentration during the glucose tolerance test ( $\geq 5 \mathrm{~min}$ ) was not affected by any dietary treatment. Dairy heifers limit-fed diets differing in forage level and $\mathrm{N}$ intake, generally responded similarly to the glucose tolerance test (Figure 3), and AUC30 was not affected by dietary treatment. This is similar to other studies in which nutritional plane was altered without producing effects on the parameters of glucose tolerance (Mann et al., 2016; MacPherson et al., 2016). Considering the large differences in dietary carbohydrate composition, it was hypothesized that heifers fed diets with increasing levels of starch would be better adapted to dispose of the exogenous glucose dose than heifers fed diets lower in starch. This hypothesis could not be accepted

Table 1. Glucose responses and kinetics for heifers fed low (LF) or high forage (HF) diets at 4 levels of N

\begin{tabular}{|c|c|c|c|c|c|c|c|c|c|c|c|}
\hline \multirow[b]{3}{*}{ Model independent responses } & \multirow[b]{3}{*}{ Forage } & & & & & \multirow[b]{3}{*}{$\mathrm{SE}$} & \multicolumn{5}{|c|}{ Contrast $^{2}$} \\
\hline & & \multicolumn{4}{|c|}{$\mathrm{N}$ intake ${ }^{1}$} & & \multirow[b]{2}{*}{ Forage } & \multicolumn{2}{|c|}{$\mathrm{N}$ Intake } & \multicolumn{2}{|c|}{ Interaction } \\
\hline & & Low & MLow & MHigh & High & & & $\mathrm{L}$ & Q & $\mathrm{L}$ & Q \\
\hline \multirow{2}{*}{$\begin{array}{l}\text { Average daily glucose, }{ }^{3} \\
\text { mg/dL }\end{array}$} & $\mathrm{LF}$ & 80.5 & 88.5 & 104.5 & 95.5 & \multirow[t]{2}{*}{8.1} & \multirow[t]{2}{*}{0.643} & \multirow[t]{2}{*}{0.663} & \multirow[t]{2}{*}{0.552} & \multirow[t]{2}{*}{0.049} & \multirow[t]{2}{*}{0.315} \\
\hline & $\mathrm{HF}$ & 93.5 & 95.7 & 80.1 & 86.3 & & & & & & \\
\hline \multirow{2}{*}{$\begin{array}{l}\text { Baseline glucose, }{ }^{4} \\
\mathrm{mg} / \mathrm{dL}\end{array}$} & $\mathrm{LF}$ & 77.6 & 78.5 & 80.6 & 81.7 & \multirow[t]{2}{*}{6.0} & \multirow[t]{2}{*}{0.671} & \multirow[t]{2}{*}{0.465} & \multirow[t]{2}{*}{0.420} & \multirow[t]{2}{*}{0.899} & \multirow[t]{2}{*}{0.401} \\
\hline & $\mathrm{HF}$ & 71.1 & 83.4 & 76.8 & 76.7 & & & & & & \\
\hline \multirow{2}{*}{$\begin{array}{l}\text { Maximum observed glucose, } \\
\text { mg/dL }\end{array}$} & $\mathrm{LF}$ & 253 & 249 & 249 & 238 & \multirow[t]{2}{*}{21} & \multirow[t]{2}{*}{0.724} & \multirow[t]{2}{*}{0.869} & \multirow[t]{2}{*}{0.277} & \multirow[t]{2}{*}{0.600} & \multirow[t]{2}{*}{0.403} \\
\hline & $\mathrm{HF}$ & 233 & 274 & 261 & 245 & & & & & & \\
\hline AUC30, ${ }^{6}$ & $\mathrm{LF}$ & 4.58 & 4.64 & 4.87 & 4.71 & \multirow[t]{2}{*}{0.33} & \multirow[t]{2}{*}{0.877} & \multirow[t]{2}{*}{0.635} & 0.195 & 0.886 & 0.414 \\
\hline $\mathrm{g} \cdot 30 \mathrm{~min} / \mathrm{dL}$ & $\mathrm{HF}$ & 4.26 & 5.20 & 4.57 & 4.58 & & & & & & \\
\hline AUC120, & $\mathrm{LF}$ & 12.14 & 12.53 & 14.15 & 13.05 & 1.00 & 0.501 & 0.064 & 0.076 & 0.803 & 0.575 \\
\hline $\mathrm{g} \cdot 120 \mathrm{~min} / \mathrm{dL}$ & $\mathrm{HF}$ & 10.31 & 13.77 & 12.07 & 12.76 & & & & & & \\
\hline Model output ${ }^{7}$ & & & & & & & & & & & \\
\hline$G_{0}, \mathrm{mg} / \mathrm{dL}$ & $\mathrm{LF}$ & 280 & 275 & 279 & 278 & 26 & 0.740 & 0.750 & 0.415 & 0.752 & 0.358 \\
\hline & $\mathrm{HF}$ & 263 & 292 & 309 & 275 & & & & & & \\
\hline$k_{g}, \% / \mathrm{h}$ & $\mathrm{LF}$ & 2.77 & 2.39 & 2.30 & 2.45 & 0.29 & 0.690 & 0.782 & 0.796 & 0.352 & 0.265 \\
\hline & $\mathrm{HF}$ & 2.60 & 2.08 & 3.25 & 2.40 & & & & & & \\
\hline$G_{b}, \mathrm{mg} / \mathrm{dL}$ & $\mathrm{LF}$ & 89 & 90 & 86 & 92 & 5 & 0.900 & 0.885 & 0.781 & 0.835 & 0.264 \\
\hline & $\mathrm{HF}$ & 83 & 102 & 81 & 89 & & & & & & \\
\hline$w$ & $\mathrm{LF}$ & 8.87 & 5.81 & 3.87 & 5.49 & 1.77 & 0.451 & 0.004 & 0.082 & 0.534 & 0.662 \\
\hline & $\mathrm{HF}$ & 11.10 & 6.90 & 6.59 & 5.23 & & & & & & \\
\hline
\end{tabular}

${ }^{1} \mathrm{~N}$ intakes were formulated to be 1.00 (Low), 1.67 (MLow), 2.33 (MHigh), and 3.00 (High) g of N/kg of metabolic BW (BW ${ }^{0.75}$ ) per day.

${ }^{2}$ Glucose concentration averaged over time throughout the day.

${ }^{3} \mathrm{~L}=$ linear; $\mathrm{Q}=$ quadratic.

${ }^{4}$ Glucose concentration observed before intravenous glucose administration (average of times -15 and -5 ).

${ }^{5}$ Maximum observed value at time $\geq 5$ min.

${ }^{6}$ Area under the curve calculated from the individual time points according to the trapezoidal rule over the indicated timeframes.

${ }^{7}$ Data for the intravenous glucose tolerance test were fitted to the following model: Plasma glucose, $\mathrm{mg} / \mathrm{dL}=G_{0} e^{-k_{g} t}+G_{b}\left(1-e^{-k_{g} t}\right)^{w}$, where $G_{0}$ is the intercept predicted at time $=0 ; k_{q}$ is the fractional rate of plasma glucose clearance; $G_{b}$ is the glucose concentration predicted at an infinite time after glucose administration; and $w$ affects the rate of approach to $G_{b}$, where a higher value for $w$ represents a prolonged long-term response to the glucose. 


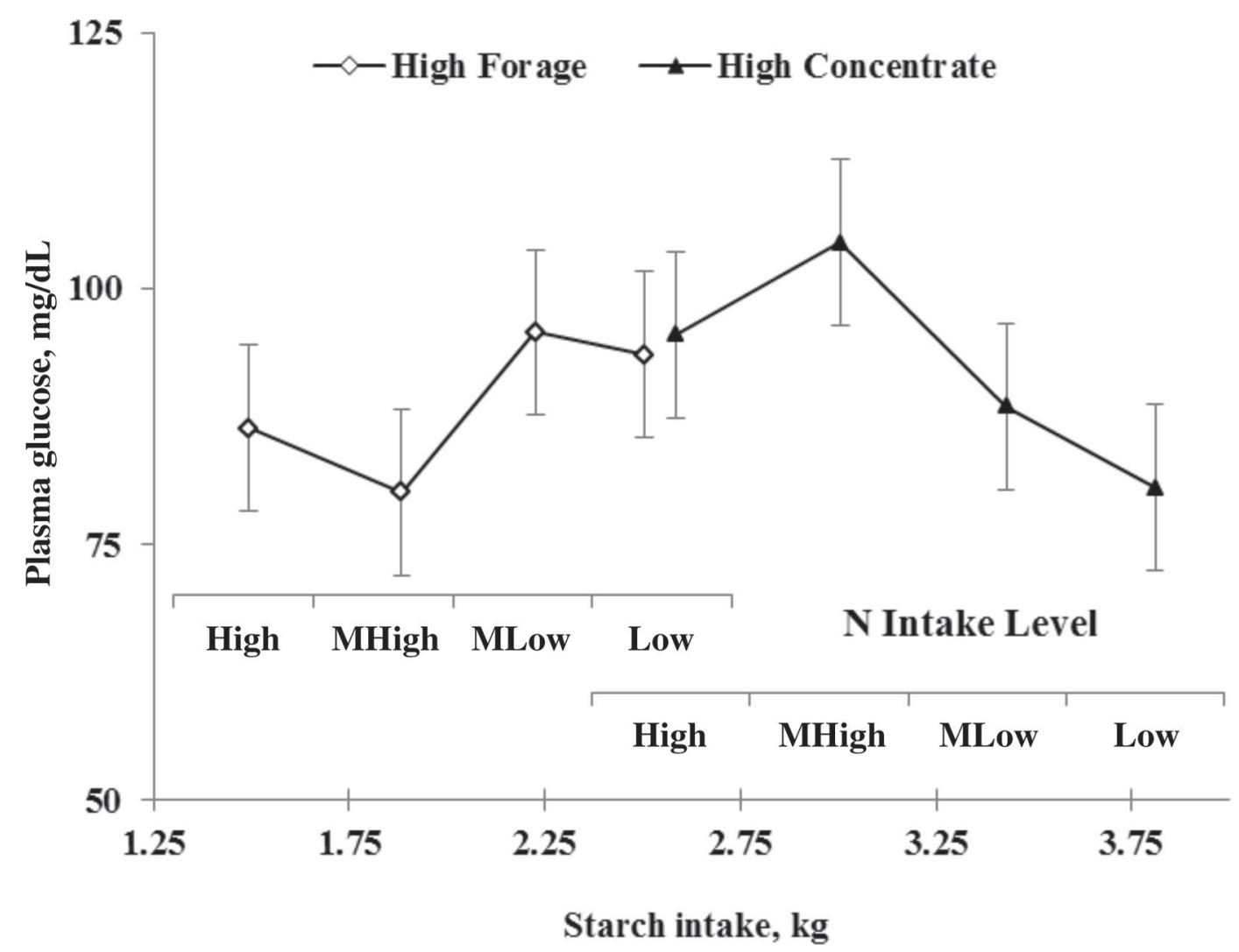

Figure 2. Association of plasma glucose concentration with starch intake for dairy heifers limit-fed low- or high-forage diets with 4 levels of nitrogen intake. Glucose concentration was affected by a linear interaction between level of forage and $\mathrm{N}$ intake $(P<0.05)$, which was quadratically associated $(P<0.05)$ with the intake of starch independent of dietary treatment classification. Nitrogen intakes were formulated to be 1.00 (Low), 1.67 (MLow), 2.33 (MHigh), and 3.00 (High) g of N/kg of metabolic BW (BW ${ }^{0.75}$ ) per day. Error bars are SEM for each time point.

based on the results of our study. Fractional rate of plasma glucose clearance after the intravenous bolus was not significantly affected by treatment and were generally higher than the clearance rates observed in the literature for a variety of physiological and nutritional states in cattle (Stanley et al., 2002; Sumner et al., 2007; MacPherson et al., 2016). The reason for the higher observed glucose clearance rate could be due to several factors: this study infused $300 \mathrm{mg}$ of glucose/ $\mathrm{kg}$ of BW, which is higher than the level used in many studies, although Bell and Jones (1945) did not observe differences in glucose clearance rates when the intravenous infusion bolus dose was 100,200 , or 500 $\mathrm{mg}$ of glucose $/ \mathrm{kg}$ of BW. Additionally, in some studies, $k_{g}$ was estimated by calculating a slope from the logtransformed glucose concentrations observed at 2 time points (Mann et al., 2016), whereas in our study data were modeled using an approach that uses the complete sample set to predict $k_{g}$.

The one parameter estimate that was significantly affected by dietary treatment was the factor $w$, which was significantly decreased as $\mathrm{N}$ intake increased. These results are consistent with AUC120, which tended to linearly increase with increasing $\mathrm{N}$ intake. Taken together, these data indicate that heifers consuming lower $\mathrm{N}$ intake had an increased longer-term responsiveness to the intravenous glucose bolus; though this response was primarily observed in heifers fed the diets with the lowest level of N (Figure 3). The glucose concentration in these heifers declined to below baseline before increasing back to baseline, whereas increasing $\mathrm{N}$ intake attenuated this response. Other studies of glucose tolerance with sampling through $180 \mathrm{~min}$ have also observed a decline in glucose concentration to below baseline values (Pires et al., 2007); however, ours is the first study we are aware of in which this response was related to $\mathrm{N}$ intake. This response, and the potential implications for carbohydrate and protein metabolism, requires further study.

In conclusion, average glucose concentration in limitfed dairy heifers was affected by an interaction between forage and $\mathrm{N}$ intake levels. Additionally, initial clearance of glucose was unaffected by dietary treatment; however, kinetics of the return to baseline glucose was 
affected by $\mathrm{N}$ intake. Finally, we concluded that glucose kinetics differ in dairy heifers fed diets differing in $\mathrm{N}$ intake, which should be considered when formulating rations for low $\mathrm{N}$ intake by replacing high- $\mathrm{N}$ for highstarch feedstuffs when limit-feeding dairy heifers.

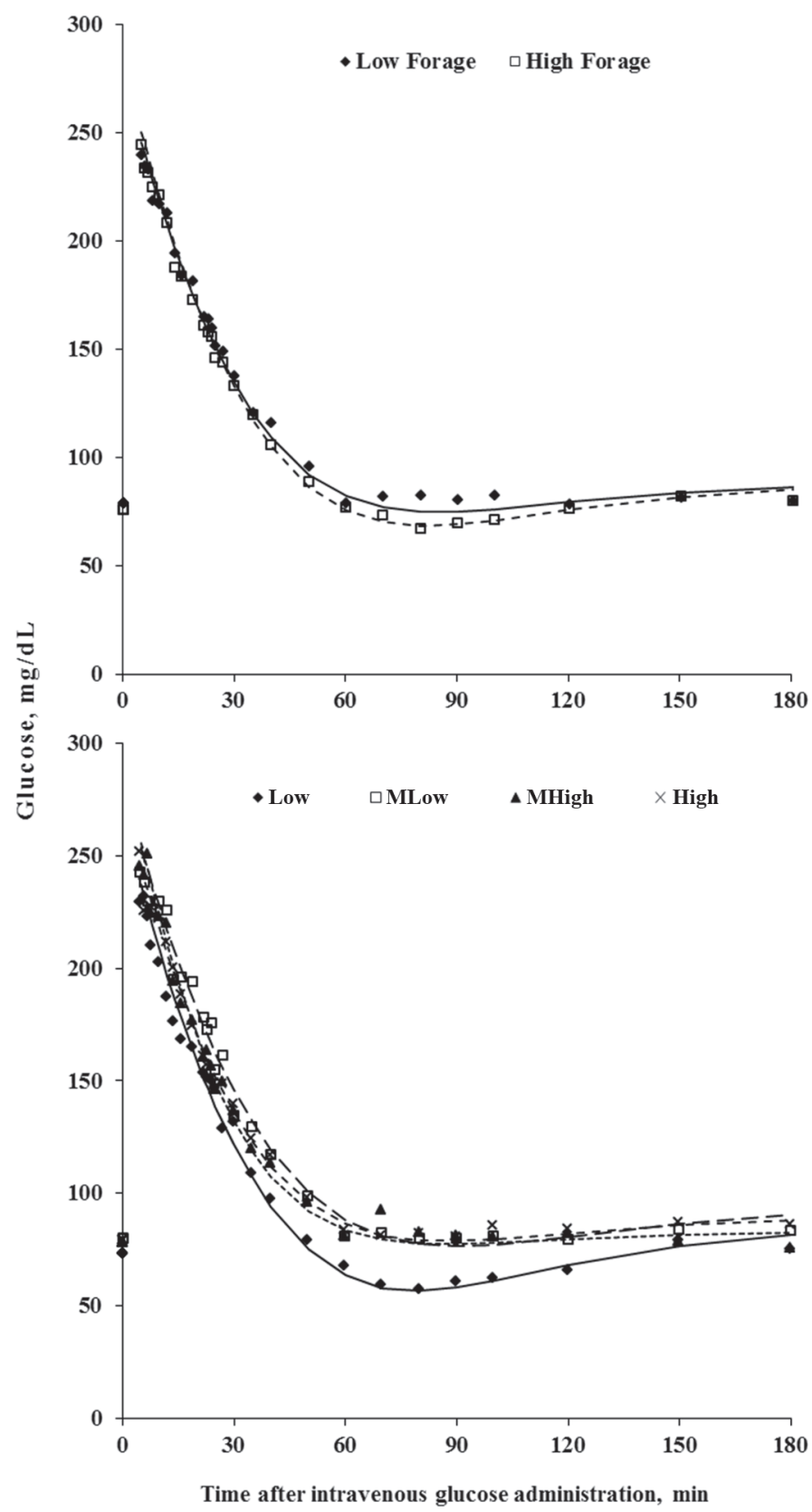

Figure 3. Average plasma glucose concentration response to an intravenous dose of glucose in dairy heifers limit-fed low- or high-forage diets with 4 levels of nitrogen intake. Nitrogen intakes were formulated to be 1.00 (Low), 1.67 (MLow), 2.33 (MHigh), and 3.00 (High) g of N/ $\mathrm{kg}$ of metabolic BW $\left(\mathrm{BW}^{0.75}\right)$ per day. Fitted responses are represented by the lines.

\section{ACKNOWLEDGMENTS}

This research was a component of and partially funded by funds from NC-2042: Management Systems to Improve the Economic and Environmental Sustainability of Dairy Enterprises.

\section{REFERENCES}

Bell, F. R., and E. R. Jones. 1945. Glucose tolerance in the bovine. J. Comp. Pathol. Ther. 55:117-124.

Bines, J. A., and A. W. F. Davey. 1978. Metabolic changes associated with intake by cows of complete diets containing straw and concentrates in different proportions. Br. J. Nutr. 39:567-578.

Cantalapiedra-Hijar, G., S. Lemosquet, J. M. Rodriguez-Lopez, F. Messad, and I. Ortigues-Marty. 2014. Diets rich in starch increase the posthepatic availability of amino acids in dairy cows fed diets at low and normal protein levels. J. Dairy Sci. 97:5151-5166.

Coggins, C. R. E., and A. C. Field. 1976. Diurnal variation in the chemical composition of plasma from lactating beef cows on three dietary energy intakes. J. Agric. Sci. 86:595-602.

Ding, L. M., G. J. Lascano, and A. J. Heinrichs. 2015. Effect of precision feeding high- and low-quality forage with different rumen protein degradability levels on nutrient utilization by dairy heifers. J. Anim. Sci. 93:3066-3075.

Evans, E., J. G. Buchanan-Smith, and G. K. Macleod. 1975. Postprandial patterns of plasma glucose, insulin and volatile fatty acids in ruminants fed low- and high-roughage diets. J. Anim. Sci. 41:1474-1479.

Hall, M. B. 2013. Dietary starch source and protein degradability in diets containing sucrose: Effects on ruminal measures and proposed mechanism for degradable protein effects. J. Dairy Sci. 96:7093-7109

Jenny, B. F., and C. E. Polan. 1975. Postprandial blood glucose and insulin in cows fed high grain. J. Dairy Sci. 58:512-514.

Kreikemeier, K. K., D. L. Harmon, R. T. Brandt, T. B. Avery, and D. E. Johnson. 1991. Small intestinal starch digestion in steers: effect of various levels of abomasal glucose, corn starch and corn dextrin infusion on small intestinal disappearance and net glucose absorption. J. Anim. Sci. 69:328-338.

Larsen, M., and N. B. Kristensen. 2013. Precursors for liver gluconeogenesis in periparturient dairy cows. Animal 7:1640-1650.

Lascano, G. J., A. J. Heinrichs, R. R. Gary, P. A. Topper, R. C. Brandt, A. Adviento-Borbe, and E. E. Fabian. 2015. Effects of forage-to-concentrate ratio and dietary fiber manipulation on gas emissions and olfactometry from manure of Holstein heifers. J. Dairy Sci. 98:1928-1937.

MacPherson, J. A., H. Berends, L. N. Leal, J. P. Cant, J. Martín-Tereso, and M. A. Steele. 2016. Effect of plane of milk replacer intake and age on glucose and insulin kinetics and abomasal emptying in female Holstein Friesian dairy calves fed twice daily. J. Dairy Sci. 99:8007-8017.

Mann, S., F. A. L. Yepes, M. Duplessis, J. J. Wakshlag, T. R. Overton, B. P. Cummings, and D. V. Nydam. 2016. Dry period plane of energy: Effects on glucose tolerance in transition dairy cows. J. Dairy Sci. 99:701-717.

Niu, M., Y. Ying, P. A. Bartell, and K. J. Harvatine. 2014. The effects of feeding time on milk production, total-tract digestibility, and daily rhythms of feeding behavior and plasma metabolites and hormones in dairy cows. J. Dairy Sci. 97:7764-7776.

NRC. 2001. Nutrient Requirements of Dairy Cattle. Natl. Acad. Press, Washington, DC.

Pires, J. A., A. H. Souza, and R. R. Grummer. 2007. Induction of hyperlipidemia by intravenous infusion of tallow emulsion causes insulin resistance in Holstein cows. J. Dairy Sci. 90:2735-2744.

Reynolds, C. K., H. F. Tyrrell, and P. J. Reynolds. 1991a. Effects of diet forage-to-concentrate ratio and intake on energy metabolism in growing beef heifers: net nutrient metabolism by visceral tissues. J. Nutr. 121:1004-1015. 
Reynolds, C. K., H. F. Tyrrell, and P. J. Reynolds. 1991b. Effects of diet forage-to-concentrate ratio and intake on energy metabolism in growing beef heifers: whole body energy and nitrogen balance and visceral heat production. J. Nutr. 121:994-1003.

Richards, C. J., A. F. Branco, D. W. Bohnert, G. B. Huntington, M. Macari, and D. L. Harmon. 2002. Intestinal starch disappearance increased in steers abomasally infused with starch and protein. J. Anim. Sci. 80:3361-3368.

Saad, M. F., R. L. Anderson, A. Laws, R. M. Watanabe, W. W. Kades, Y.-D. I. Chen, R. E. Sands, D. Pei, P. J. Savage, and R. N. Bergman. 1994. A comparison between the minimal model and the glucose clamp in the assessment of insulin sensitivity across the spectrum of glucose tolerance. Diabetes 43:1114-1121.

SAS Institute. 2013. SAS User's Guide: Statistics. Version 9.4. SAS Inst. Inc., Cary, NC.

Stanley, C. C., C. C. Williams, B. F. Jenny, J. M. Fernandez, H. G. Bateman, W. A. Nipper, J. C. Lovejoy, D. T. Gantt, and G. E.
Goodier. 2002. Effects of feeding milk replacer once versus twice daily on glucose metabolism in Holstein and Jersey calves. J. Dairy Sci. 85:2335-2343.

Sumner, J. M., F. Valdez, and J. P. McNamara. 2007. Effects of chromium propionate on response to an intravenous glucose tolerance test in growing Holstein heifers. J. Dairy Sci. 90:3467-3474.

Van Soest, P. J. 1994. Nutritional Ecology of the Ruminant. Cornell University Press, Ithaca, NY.

Zanton, G. I., and A. J. Heinrichs. 2005. Meta-analysis to assess effect of prepubertal average daily gain of Holstein heifers on firstlactation production. J. Dairy Sci. 88:3860-3867.

Zanton, G. I., and A. J. Heinrichs. 2009. Digestion and nitrogen utilization in dairy heifers limit-fed a low or high forage ration at four levels of nitrogen intake. J. Dairy Sci. 92:2078-2094.

Zanton, G. I., and A. J. Heinrichs. 2016. Efficiency and rumen responses in younger and older Holstein heifers limit-fed diets of differing energy density. J. Dairy Sci. 99:2825-2836. 